\title{
Critical Review of Complementary and Alternative Medicine Use in Amyotrophic Lateral Sclerosis: Prevalence and Users' Profile, Decision-Making, Information Seeking, and Disclosure in the Face of a Lack of Efficacy
}

\author{
Jon Adams ${ }^{a}$ Michael Lee ${ }^{b}$ Wenbo Peng ${ }^{a}$ \\ ${ }^{a}$ Faculty of Health, University of Technology Sydney, Sydney, NSW, Australia; ${ }^{b}$ Graduate School of Health, Discipline of \\ Physiotherapy, University of Technology Sydney, Sydney, NSW, Australia
}

\section{Keywords \\ Amyotrophic lateral sclerosis - Complementary and alternative medicine $\cdot$ Review $\cdot$ Prevalence $\cdot$ Decision- making $\cdot$ Information seeking $\cdot$ Disclosure}

\begin{abstract}
Background: Despite a lack of evidence of clinical efficacy for complementary and alternative medicine (CAM) use in amyotrophic lateral sclerosis (ALS), these medicines remain popular around the world. Objective: To examine the prevalence and cost of CAM use in ALS and CAM users' profile, decision-making, information seeking, and disclosure among ALS patients. Methods: A comprehensive literature search was conducted of MEDLINE, CINAHL/SCOPUS, and AMED databases from their inception to April 2018. This review followed PRISMA guidelines and employed a quality scoring system to assess the included papers. Results: Seven papers met the inclusion criteria and were thematically analysed. ALS patients utilized a range of CAM therapies and/or products, with acupuncture and vitamins being the most frequently reported. CAM modalities were often employed concurrently with conventional medications throughout the disease process. Although some ALS patients reported posi-
\end{abstract}

๑) 2018 S. Karger AG, Basel tive experience regarding CAM use, many were reluctant to disclose their CAM use to their clinicians. Research focusing on CAM use in ALS remains ad hoc and restricted to only a few countries. The rigour and quality of this research field to date has been varied, predominantly drawing upon regional/localized data and failing to report CAM users' characteristics. Conclusion: A proportion of ALS patients report utilizing CAM concurrently with conventional treatments. Such use, set amidst a dearth of evidence for the efficacy of CAM in ALS, poses potential direct and indirect risks to patient care, and medical providers should be mindful of and enquire about CAM use when treating ALS patients.

(c) 2018 S. Karger AG, Basel

\section{Introduction}

Amyotrophic lateral sclerosis (ALS) is a neurodegenerative disease primarily affecting the motor system and characterized by progressive degeneration of the motor neurons $[1,2]$. The prevalence of ALS cases is estimated to increase by almost one third from 2015 to 2040 [3]. ALS poses a substantial economic burden and significantly influences the quality of life of patients, families,

\section{KARGER}

E-Mail karger@karger.com

www.karger.com/ndd
Prof. Jon Adams

Faculty of Health, Level 8, Building 10

University of Technology Sydney

235-253 Jones St, Ultimo, NSW 2007 (Australia)

E-Mail Jon.Adams@uts.edu.au 
and wider communities $[4,5]$. The average lifespan of ALS patients is approximately 2-4 years from the onset of symptoms [6] with no known cure for ALS at present [7].

Patients who are aware of the absence of effective/curative treatments for their medical conditions often consider using complementary and alternative medicine (CAM) to relieve symptoms and/or improve quality of life, and this is no different for those with neurodegenerative diseases [8-11]. CAM refers to a wide range of practices not traditionally included in the remit of the mainstream medical profession or medical curriculum [12]. Despite the widespread use of CAM among people with some neurodegenerative disorders $[10,11]$, only one review paper focusing upon the clinical efficacy of CAM for ALS has been published to date [13]. This review reported the effect of most CAM as generally unproven with pockets of emerging evidence and highlighted conflicting evidence regarding the effect of dietary supplements, chelation therapy, and acupuncture for ALS management.

In light of the efficacy evidence vacuum for CAM in ALS, it is important to establish the details of CAM use by ALS patients in order to ensure safe, effective care free from potential risks. Unfortunately, there has been no critical review examining the prevalence and cost of CAM use in ALS, or ALS CAM users' profile, decision-making, information seeking, and disclosure. In response, this paper reports the results of a critical review of the contemporary empirical literature examining CAM use among ALS patients.

\section{Methods}

This review has been registered on the PROSPERO international prospective register of systematic reviews (\#CRD42017082229). All data included in this review were extracted from published articles, thus no Ethics Board approval was required.

\section{Search Methods}

The databases MEDLINE, CINAHL via EBSCO, and AMED were searched from the inception years of these databases to April 2018 employing keywords and MeSH words for ALS and CAM: ("amyotrophic lateral sclerosis" OR "motor neuron disease" OR "Lou Gehrig's disease" OR "bulbar palsy" OR "muscular atrophy" OR "Charcot disease" OR "ALS" OR "MND" OR "progressive muscular dystrophies") AND ("complementary medicine" OR "complementary therapy" OR "alternative medicine" OR "alternative therapy" OR "acupuncture" OR "energy healing" OR "homeopathy" OR "osteopathy" OR "chiropractic" OR "Chinese medicine" OR "aromatherapy" OR "naturopathy" OR "massage" OR "vitamin" OR "dietary supplement" OR "meditation" OR "herbal medicine" OR "yoga"). Additional hand-searching via Google Scholar regarding the bibliographies of identified ALS-related review papers was undertaken to guarantee that all relevant literature was included.

\section{Eligibility Criteria}

The references obtained from each database were imported into EndNote X8. Three authors screened all retrieved titles and abstracts to identify papers reporting empirical research findings. The full texts of potential eligible articles were examined by the authors prior to inclusion and were excluded in those cases where the title and abstract failed to provide sufficient information. Articles were included in the review if they were published in peerreviewed journals, reported findings from empirical studies investigating the use of CAM in ALS (directly or among examination of ALS management more generally), and were written in English. Papers identified as clinical trials, editorials, commentaries, or case reports were excluded from the review.

\section{Search Outcomes}

The review followed the PRISMA guideline "Preferred reporting items for systematic reviews and meta-analyses" [14]. The initial search identified 2,537 papers after duplicates were removed. Of these, a total of seven articles from seven studies met the inclusion criteria and were included in the review. Figure 1 presents the PRISMA flowchart of the search process and paper selection. Tables 1 and 2 show general information on the research design and results of each article, respectively.

\section{Quality Appraisal}

A modified quality scoring system (Table 3) previously used for appraising CAM use literature in a variety of diseases/conditions was employed to assess the quality of the papers identified for our review $[15,16]$. Three authors assigned scores to each paper separately utilizing the scoring system and any differences in score results across authors were resolved via discussion. Table 4 demonstrates the summary of the quality score of each paper.

\section{Results}

A critical review method was employed to extract and summarize the context and findings of the seven papers identified [17]. The findings identified were synthesized into four themes: "prevalence of CAM use in ALS", "CAM users' profile and cost of CAM use in ALS", "decisionmaking for CAM use in ALS", and "information seeking and disclosure to clinicians of CAM use in ALS".

\section{Prevalence of CAM Use in ALS}

Only two out of the seven papers included in this review reported a prevalence rate of CAM use among ALS patients $[18,19]$. A cross-sectional study in Germany published in 2001 reported a CAM use rate of $54 \%$ among 171 ALS patients who were members of the German Association for Neuromuscular Disease [18]. Another cross- 
Fig. 1. PRISMA flow diagram of the results of the literature search.

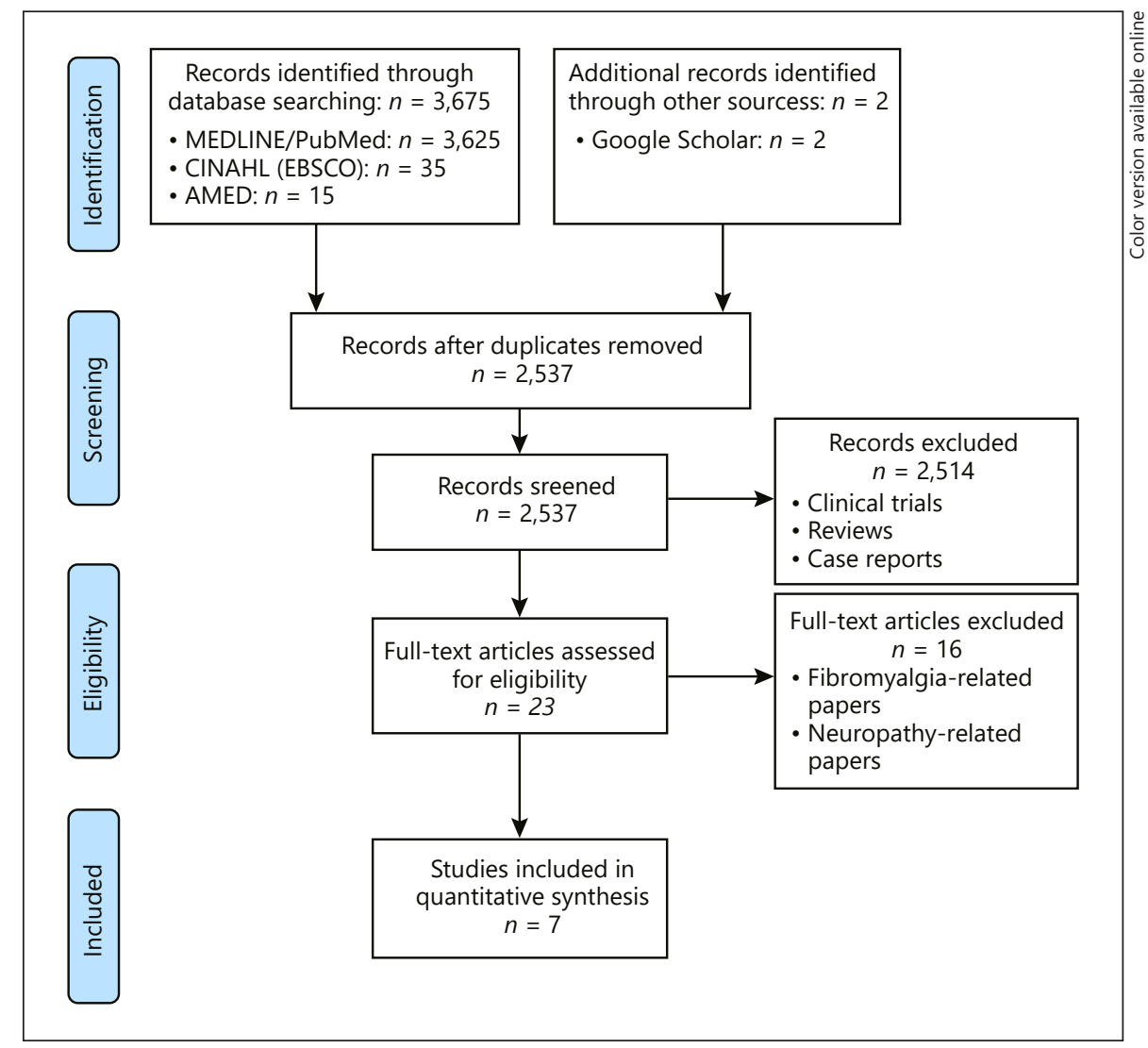

sectional study conducted in 2012-2013 in ALS patients from 12 hospitals in one Chinese city found that $99 \%$ of the respondents $(n=229)$ had used at least one CAM [19].

All the quantitative studies identified described the CAM therapies used by ALS patients and the majority provided rates for individual CAM. Acupuncture [18-21] and vitamins $[18,19,21,22]$ were the most commonly used CAM in ALS, followed by Chinese medicine $[18,19$, 22], massage therapy [19-21], and dietary/herbal supplements $[18,21,23]$. The prevalence of acupuncture, vitamins, Chinese medicine, massage therapy, and dietary/ herbal supplements was reported to range from 2 to $51 \%$ (mean 26\%), from 15 to $91 \%$ (mean 54\%), from 11 to $95 \%$ (mean 52\%), from 4 to $57 \%$ (mean 23\%), and from 16 to $42 \%$ (mean 26\%), respectively. Among the vitamin and dietary/herbal supplement use in ALS, the prevalence of vitamin $\mathrm{E}$ and coenzyme Q10 were particularly highlighted in four papers [18, 19, 21, 23].

Notably, two studies showed that ALS patients were likely to use multiple CAM throughout the course of their patient journey. In a German study, some ALS patients reported using up to 11 CAM [18]. Approximately half of the ALS patients used more than five CAM in a Chinese study [19]. Additionally, three studies undertaken in Germany and China identified most ALS patients as concurrently using CAM alongside riluzole [18-20].

\section{CAM Users' Profile and Cost of CAM Use in ALS}

Regarding the characteristics of CAM users or predictors of CAM use among ALS patients, only one German study published in 2001 reported rich information (e.g., age, gender, and duration of ALS). It is worth noting that $60 \%$ of patients in this German study who used CAM had limb onset of ALS [18]. Four studies included in our review examined the predictors of CAM use in ALS [18, 19, $21,22]$, showing that patients who used CAM were more likely to be younger $[18,21]$ and reported a higher income $[18,19]$. Furthermore, two papers reported that gender was not a significant factor regarding Chinese medicine use among ALS patients $[19,22]$. In addition, a study in Germany reported the average cost of CAM use as USD 4,700 per year with $65 \%$ of the CAM users identified in this study not eligible to receive health care reimbursement on CAM [18]. Another study in China reported the 
Table 1. General information of included studies

\begin{tabular}{|c|c|c|c|c|c|c|}
\hline Author/year & Country & Study design & Patient source & Inclusion/exclusion criteria & Sample size & $\begin{array}{l}\text { Data collection } \\
\text { period }\end{array}$ \\
\hline $\begin{array}{l}\text { Hanisch et al. } \\
{[20], 2015}\end{array}$ & Germany & $\begin{array}{l}\text { Cross-sectional } \\
\text { survey }\end{array}$ & $\begin{array}{l}\text { Not national data } \\
\text { (outpatient ALS } \\
\text { clinic data) }\end{array}$ & $\begin{array}{l}\text { Inclusion criteria: Diagnosed ALS according } \\
\text { to the revised El Escorial criteria } \\
\text { Exclusion criteria: Patients with dementia }\end{array}$ & $\begin{array}{l}46 \\
\text { (response rate: } \\
84 \%)\end{array}$ & $\begin{array}{l}\text { March } 2013 \text { to } \\
\text { September } 2013\end{array}$ \\
\hline $\begin{array}{l}\text { Kim et al. } \\
{[24], 2016}\end{array}$ & Korea & $\begin{array}{l}\text { Semi-structured } \\
\text { interviews }\end{array}$ & $\begin{array}{l}\text { Not national data } \\
\text { (medical hospital } \\
\text { and home care } \\
\text { services data) }\end{array}$ & $\begin{array}{l}\text { Inclusion criteria: Hospitalized ALS patients } \\
\text { and their families who have used CAM after } \\
\text { ALS diagnosis and the ability to express by } \\
\text { self or through caregivers } \\
\text { Exclusion criteria: ALS patients who had used } \\
\text { CAM only before ALS diagnosis and those } \\
\text { with cognitive disorders }\end{array}$ & $\begin{array}{l}9 \text { ALS patients } \\
\text { and } 7 \text { family } \\
\text { members } \\
\text { (response rate: } \\
\text { N/A) }\end{array}$ & $\begin{array}{l}\text { March } 2013 \text { to } \\
\text { September } 2013\end{array}$ \\
\hline $\begin{array}{l}\text { Chen et al. } \\
{[22], 2016}\end{array}$ & China & $\begin{array}{l}\text { Cohort study } \\
\text { (longitudinal } \\
\text { data) }\end{array}$ & $\begin{array}{l}\text { Not national data } \\
\text { (database of an ALS } \\
\text { centre) }\end{array}$ & $\begin{array}{l}\text { Inclusion criteria: Diagnosed ALS according } \\
\text { to the Airlie House diagnostic criteria } \\
\text { Exclusion criteria: N/A }\end{array}$ & $\begin{array}{l}1,624 \\
\text { (response rate: } \\
\text { N/A) }\end{array}$ & $\begin{array}{l}\text { January } 2003 \text { to } \\
\text { December } 2012\end{array}$ \\
\hline $\begin{array}{l}\text { Wasner et al. } \\
{[18], 2001}\end{array}$ & Germany & $\begin{array}{l}\text { Cross-sectional } \\
\text { survey }\end{array}$ & $\begin{array}{l}\text { Not national data } \\
\text { (Association for } \\
\text { Neuromuscular } \\
\text { Diseases data) }\end{array}$ & $\begin{array}{l}\text { Inclusion criteria: Patients with established } \\
\text { diagnosis of ALS } \\
\text { Exclusion criteria: N/A }\end{array}$ & $\begin{array}{l}171 \\
\text { (response rate: } \\
49 \%)\end{array}$ & N/A \\
\hline $\begin{array}{l}\text { Vardeny and } \\
\text { Bromberg } \\
{[21], 2005}\end{array}$ & USA & $\begin{array}{l}\text { Cross-sectional } \\
\text { survey }\end{array}$ & $\begin{array}{l}\text { Not national data } \\
\text { (ALS clinic data) }\end{array}$ & $\begin{array}{l}\text { Inclusion criteria: N/A } \\
\text { Exclusion criteria: Patients who were physically } \\
\text { unable to fill out the questionnaire or had no } \\
\text { carer to help them fill out the survey }\end{array}$ & $\begin{array}{l}53 \\
\text { (response rate: } \\
44 \%)\end{array}$ & $\begin{array}{l}\text { January } 2002 \text { to } \\
\text { February } 2002\end{array}$ \\
\hline $\begin{array}{l}\text { Pan et al. } \\
{[19], 2013}\end{array}$ & China & $\begin{array}{l}\text { Cross-sectional } \\
\text { survey }\end{array}$ & $\begin{array}{l}\text { Not national data. } \\
\text { (data from } 12 \\
\text { hospitals in one city) }\end{array}$ & $\begin{array}{l}\text { Inclusion criteria: Diagnosed ALS according } \\
\text { to the revised El Escorial criteria } \\
\text { Exclusion criteria: Patients with dementia }\end{array}$ & $\begin{array}{l}231 \\
\text { (response rate: } \\
90 \% \text { ) }\end{array}$ & $\begin{array}{l}\text { December } 2012 \\
\text { to May } 2013\end{array}$ \\
\hline
\end{tabular}

CAM, complementary and alternative medicine.

average cost of CAM use for ALS to be USD 270 per month per patient [19].

\section{Decision-Making for CAM Use in ALS}

Only one qualitative study undertaken in Korea reported detailed perceptions of ALS patients and their family members regarding CAM use [24]. The data from this study showed that some ALS patients perceived all CAM as "functional health food" rather than medicine and some perceived that their CAM practitioners might overestimate the positive effect of CAM regarding the management of ALS.

A number of reported studies identified "slowing disease progression", "relieving symptoms", and "managing side effects associated with riluzole" as popular reasons for ALS patients seeking CAM use [18, 19, 21]. Concerning the relief of ALS symptoms via CAM use, magnesium and acu- puncture/massage therapy have been used for the management of ALS-related cramps and pain, respectively [20], and Chinese medicine was found to be used for weakness and fatigue, muscle atrophy, and/or limb pain [19].

There appear to be no consistent findings regarding the patient-reported outcome of CAM in ALS as outlined in three studies in Korea, Germany, and China [18, 19, 24]. All these studies showed that some ALS patients reported CAM use as beneficial (ranging from 9\% of 231 patients to $60 \%$ of 171 patients), and up to $63 \%$ of ALS patients continued to use CAM despite reporting no perceivable benefits from use $[18,19,24]$. However, a proportion of ALS patients reported receiving no benefits and some reported unwanted side effects from CAM use such as worsening of fasciculation and gastrointestinal discomfort $[18,24]$. 
Table 2. Information on complementary and alternative medicine (CAM) use in ALS

\begin{tabular}{|c|c|c|c|c|c|c|c|c|}
\hline Author/year & CAM use rate & Modality & Patients' profile & Perceptions of CAM use & Reasons for CAM use & Effectiveness of CAM & $\begin{array}{l}\text { Information source of } \\
\text { CAM }\end{array}$ & $\begin{array}{l}\text { Communication with } \\
\text { clinicians }\end{array}$ \\
\hline $\begin{array}{l}\text { Hanisch } \\
\text { et al. } \\
\text { [20], } 2015\end{array}$ & N/A & $\begin{array}{l}\text { Magnesium }(16 \%) ; \\
\text { acupuncture }(4 \%) ; \\
\text { massage }(4 \%)\end{array}$ & N/A & N/A & N/A & N/A & N/A & N/A \\
\hline $\begin{array}{l}\text { Kim } \\
\text { et al. } \\
\text { [24], } 2016\end{array}$ & N/A & N/A & N/A & $\begin{array}{l}\text { Overestimated CAM } \\
\text { (some CAM } \\
\text { practitioners); slight } \\
\text { possibility of complete } \\
\text { cure of ALS by CAM; } \\
\text { CAM is functional } \\
\text { health food }\end{array}$ & $\begin{array}{l}\text { Friends' recommendation; } \\
\text { no conventional medical } \\
\text { treatments; previous CAM } \\
\text { use; easily accessible CAM } \\
\text { products; encouraging } \\
\text { results with CAM }\end{array}$ & $\begin{array}{l}\text { Feeling relaxed } \\
\text { physically and } \\
\text { emotionally; improved } \\
\text { symptoms; no visible } \\
\text { effects but continuing to } \\
\text { use CAM }\end{array}$ & $\begin{array}{l}\text { Media (no rate } \\
\text { reported); internet } \\
\text { (no rate reported) }\end{array}$ & $\begin{array}{l}\text { Discussed CAM with } \\
\text { clinicians who were in } \\
\text { favour of CAM; did not } \\
\text { inform their clinicians of } \\
\text { CAM use even when they } \\
\text { improved with CAM }\end{array}$ \\
\hline $\begin{array}{l}\text { Chen } \\
\text { et al. } \\
\text { [22], } 2016\end{array}$ & N/A & $\begin{array}{l}\text { Vitamins ( } 40 \%) ; \\
\text { Chinese medicine } \\
(11 \%)\end{array}$ & N/A & N/A & N/A & N/A & N/A & N/A \\
\hline $\begin{array}{l}\text { Jefferies and } \\
\text { Bromberg } \\
{[23], 2012}\end{array}$ & N/A & $\begin{array}{l}\text { Dietary supplement } \\
\text { (19\%); Q10 (N/A) }\end{array}$ & N/A & N/A & N/A & N/A & N/A & N/A \\
\hline $\begin{array}{l}\text { Wasner } \\
\text { et al. } \\
{[18], 2001}\end{array}$ & $\begin{array}{l}54 \% \\
(n=92)\end{array}$ & $\begin{array}{l}73 \text { CAM, e.g., vitamin E } \\
\text { (76\%); acupuncture } \\
(47 \%) \text {; homeopathy } \\
(40 \%)\end{array}$ & $\begin{array}{l}\text { Average } 56 \text { years; } \\
58 \% \text { female; } 60 \% \\
\text { with limb onset; } \\
72 \% \text { with previous } \\
\text { use of riluzole; } \\
\text { average USD 4,700 } \\
\text { on CAM per year; } \\
84 \% \text { with regular } \\
\text { clinician visits }\end{array}$ & N/A & N/A & $\begin{array}{l}60 \% \text { reporting positive } \\
\text { effect; } 38 \% \text { reporting no } \\
\text { effect; } 2 \% \text { reporting } \\
\text { disease worsening }\end{array}$ & $\begin{array}{l}\text { Friends or relatives } \\
(50 \%) \text {; clinicians } \\
(25 \%) \text {; media and } \\
\text { internet }(17 \%)\end{array}$ & $\begin{array}{l}78 \% \text { informed clinicians } \\
\text { about CAM use; } 60 \% \\
\text { reporting CAM } \\
\text { administered by clinicians } \\
\text { and } 30 \% \text { by self-care; } \\
\text { clinicians against CAM } \\
\text { being the most common } \\
\text { reason for not reporting } \\
\text { CAM use }\end{array}$ \\
\hline $\begin{array}{l}\text { Vardeny and } \\
\text { Bromberg } \\
{[21], 2005}\end{array}$ & N/A & $\begin{array}{l}\text { Herbal medicine }(42 \%) \text {; } \\
\text { vitamins }(70 \%) \text {; other } \\
\text { CAM therapies }(15 \%)\end{array}$ & N/A & N/A & $\begin{array}{l}\text { To relieve symptoms and } \\
\text { slow disease progression }\end{array}$ & N/A & $\begin{array}{l}\text { Clinicians (51\%); } \\
\text { friends/family (44\%); } \\
\text { books or magazines } \\
(17 \%) \text {; interne }(17 \%)\end{array}$ & $\begin{array}{l}56 \% \text { informed and discussed } \\
\text { with neurologists or } \\
\text { primary care providers } \\
\text { about their use of CAM }\end{array}$ \\
\hline $\begin{array}{l}\text { Pan } \\
\text { et al. } \\
\text { [19], } 2013\end{array}$ & $\begin{array}{l}99 \% \\
(n=229)\end{array}$ & $\begin{array}{l}\text { Several CAM therapies, } \\
\text { e.g., vitamin E ( }(95 \%) \text {; } \\
\text { Chinese medicine } \\
(91 \%) ; \text { massage }(57 \%)\end{array}$ & $\begin{array}{l}\text { Average USD } 270 \\
\text { per month of CAM } \\
\text { use; } 89 \% \text { without } \\
\text { previous CAM use } \\
\text { experience }\end{array}$ & $1^{\mathrm{N} / \mathrm{A}}$ & $\begin{array}{l}\text { To relieve symptoms (e.g., } \\
\text { weakness/fatigue, muscle } \\
\text { atrophy, depression), slow } \\
\text { disease progression, and treat } \\
\text { riluzole-related side effects }\end{array}$ & $\begin{array}{l}25 \% \text { with improved } \\
\text { subject symptoms (e.g., } \\
\text { feeling comfortable, } \\
\text { slightly happier); } 63 \% \\
\text { reporting no obvious } \\
\text { effects }\end{array}$ & $\begin{array}{l}\text { Friends/family }(68 \%) \text {; } \\
\text { media }(53 \%) ; \text { health } \\
\text { care practitioners } \\
(36 \%) \text {; internet }(66 \%)\end{array}$ & $\begin{array}{l}78.2 \% \text { of CAM users did not } \\
\text { consult their clinicians } \\
\text { before starting CAM }\end{array}$ \\
\hline
\end{tabular}

Table 3. The quality scoring system employed in the review

Dimensions of quality assessment

Points awarded ${ }^{\mathrm{a}}$

\section{Methodology}

A Representative sampling strategy 1

B Sample size $>500$

C Response rate $>75 \%$

D Low recall bias (prospective data collection or retrospective data collection within past 12 months)

Reporting of participants' characteristics

E ALS eligible criteria/symptoms

F Age

G Ethnicity

$\mathrm{H}$ Indicator of socioeconomic status (e.g., income, education)

1
1
1

Reporting of CAM use

I Definition of CAM or modalities provided to participants 1

J Participants can describe the CAM therapies/modalities used 1

$\mathrm{K}$ Use of CAM modalities assessed

${ }^{\text {a }}$ Maximum score: 11 points. 
Table 4. Quality evaluation of included studies

\begin{tabular}{lllll}
\hline Author/year & \multicolumn{2}{c}{ Dimensions of quality assessment } & Total \\
\cline { 2 - 3 } & methodology & $\begin{array}{l}\text { reporting of partici- } \\
\text { pants' characteristics }\end{array}$ & $\begin{array}{c}\text { reporting of } \\
\text { CAM use }\end{array}$ & score \\
\hline Chen et al. [22], 2016 & $2(\mathrm{~B}, \mathrm{C})$ & $2(\mathrm{E}, \mathrm{F})$ & $2(\mathrm{I}, \mathrm{K})$ & 6 \\
Kim et al. [24], 2016 & $2(\mathrm{C}, \mathrm{D})$ & $2(\mathrm{E}, \mathrm{F})$ & $2(\mathrm{~J}, \mathrm{~K})$ & 6 \\
Hanisch et al. [20], 2015 & $2(\mathrm{C}, \mathrm{D})$ & $2(\mathrm{E}, \mathrm{F})$ & $1(\mathrm{~K})$ & 5 \\
Pan et al. [19], 2013 & $2(\mathrm{C}, \mathrm{D})$ & $3(\mathrm{E}, \mathrm{F}, \mathrm{H})$ & $3(\mathrm{I}, \mathrm{J}, \mathrm{K})$ & 8 \\
Jefferies and Bromberg [23], 2012 & $1(\mathrm{D})$ & $2(\mathrm{E}, \mathrm{F})$ & $1(\mathrm{~K})$ & 4 \\
Vardeny and Bromberg [21], 2005 & $1(\mathrm{D})$ & $3(\mathrm{E}, \mathrm{F}, \mathrm{H})$ & $3(\mathrm{I}, \mathrm{J}, \mathrm{K})$ & 7 \\
Wasner et al. [18], 2001 & 0 & $3(\mathrm{E}, \mathrm{F}, \mathrm{H})$ & $3(\mathrm{I}, \mathrm{J}, \mathrm{K})$ & 6 \\
\hline
\end{tabular}

See Table 3 for explanation of dimensions of quality assessment.

\section{Information Seeking and Disclosure to Clinicians regarding CAM Use in ALS}

Four identified studies reported ALS patients as drawing upon consistent information sources for CAM including "the internet" with the range of prevalence rates from 17 to $66 \%$ (mean 33\%) [18, 19, 21, 24], "friends or relatives" with the range of rates from 44 to $68 \%$ (mean $54 \%)[18,19,21]$, and "clinicians" with the range of rates from 25 to $51 \%$ (mean 37\%) [18, 19, 21]. More than $60 \%$ of ALS patients and their caregivers in a Chinese study considered the internet a primary referral source, which was almost double the number of those who sought help from a physician to gain CAM information [19].

The same four studies reporting ALS patients' information seeking of CAM use also examined the attitude of clinicians towards CAM and its influence upon ALS patients' CAM use $[18,19,21,24]$. Up to $78 \%$ of ALS patients only informed and discussed their use of CAM with their clinicians (i.e., neurologist or primary care provider) when the physician showed a positive attitude towards or were deemed to be "open" to CAM $[18,21,24]$. In contrast, three studies identified a substantial proportion of ALS patients who failed to inform their physician about their CAM use even in cases where they experienced some improvement in their symptoms following use [18, 19, 24]. This reported reluctance among some ALS patients using CAM to disclose such use to their physician was due to patients fearing their clinicians may subsequently decline care in response to continued CAM use $[18,24]$.

\section{Appraisal Outcomes}

Seven studies were appraised by a quality scoring system and were identified to be of diverse methodological quality via the quality scores (Table 4 ). The vast majority of these studies avoided high recall bias with the crosssectional study designs collecting data from ALS patients who used CAM within a 6 -month period. Three of the reviewed studies failed to report a response rate $>75 \%$. No study reported the ethnicity of participants and only three studies identified the socioeconomic characteristics of participating CAM users. Two studies neither explained the definition of CAM therapies to participants as part of their fieldwork design nor allowed participants to describe their CAM modalities used. Overall, the information regarding CAM use for the management of ALS and CAM user profile remains limited.

\section{Discussion}

This paper is the first critical review of international literature on CAM use among ALS patients. While the body of literature on CAM use in ALS is indeed small, it appears that this topic may be gaining some interest from the research community with five out of the seven studies identified in our review published since 2012. Such research interest has also been presented in the launch of an internet-based platform exclusive for ALS patients ALSUntangled (http://www.alsuntangled.com/). Information on the potential benefits of a range of CAM practices has been frequently requested by ALS patients via ALSUntangled, and the ALSUntangled team has published several narrative reviews on the effects and risks of various CAM for ALS.

Our review highlights a lack of research focusing upon the utilization of CAM in ALS, with only seven such studies identified to date. Only two of these seven studies have 
reported the overall prevalence of CAM use for the management of ALS and only one study carried out in 2001 has investigated the profile of CAM users among ALS patients. None of the included studies in this review focused upon the change of ALS patients' quality of life after their CAM use. Additionally, limited empirical information is currently available on the possible symptomatic benefits from CAM use and the wider issue of ALS patients' decision-making regarding CAM use.

Two studies reporting the prevalence of CAM use among ALS patients indicate rates above $50 \%$ of their respective cohorts - a finding in line with the prevalence of CAM use identified among patients with other neurological and neurodegenerative diseases including multiple sclerosis $[7,25]$. Among the CAM users identified in our review, some not only used multiple CAM during the course of their disease but also used CAM concurrently with riluzole for the management of ALS. The reason for such CAM use in ALS remains unknown and this significant research gap needs further in-depth examination. In particular, medical practitioners need to be aware of the possible direct and indirect risks caused by the concurrent use of CAM and conventional ALS treatment(s) [10] - challenges further exacerbated by a finding of our review that ALS patients report significant levels of non-disclosure to clinicians regarding their CAM use. Therefore, communication and non-disclosure of CAM use and a more in-depth understanding of CAM user profile among ALS patients and their decision-making processes are ostensibly significant issues for all health care providers involved in the care of ALS patients. Indeed, the evidence shown in this review suggests that the response and attitude of the medical practitioner towards CAM may play a significant role in ALS patient decision-making around CAM use.

The existing positive perception and acceptance of CAM by ALS patients shown in this review add focus to a clinical debate regarding the relative merits of CAM for ALS in addition to conventional treatments. While multidisciplinary care is the gold-standard treatment for ALS at present [26] and is delivered by a coordinated team of health care practitioners [27], the integration of CAM into such an approach is currently highly improbable. Further evidence of efficacy is required if CAM is to be systematically integrated as a complement to conventional care, and whether such concurrent use is worthy of time and investment from all involved in ALS patient care remains questionable in the absence of relevant empirical enquiry. Nevertheless, it is not feasible to ignore CAM use

Complementary and Alternative Medicine

Use in ALS among ALS patients as either a research or clinical topic. Further research is necessary to explore in detail who, why, and how CAM is utilized by ALS patients as well as provide in-depth examination regarding the barriers and drivers of communication and disclosure around CAM use among ALS patients and clinicians. This future work can provide an essential evidence platform for all those managing, providing, and seeking ALS care and help to ensure ALS patient management remains safe, effective, and coordinated.

An important limitation of this critical review lies in the fact that all studies reviewed were restricted to English language peer-reviewed journal articles. Also, interpreting CAM use findings across all the studies is not without challenge due to the various practices and products included under CAM categorizations employed in different studies within and across countries. Nevertheless, this review provides the first critical evaluation of current research literature on CAM use among ALS patients, revealing insights for researchers, policy makers, and health care/medical providers regarding important aspects of ALS management and patient care.

\section{Conclusions}

Concurrent CAM use with medical treatments among ALS patients poses potential direct and indirect risks, and medical providers should be mindful of and enquire about CAM use among their ALS patients. Rigorous, large-scale research drawing upon national ALS patient samples is required to shed light on the details of CAM use and CAM users' profile and decision-making processes in order to help ensure effective, safe patient care for all ALS patients.

\section{Disclosure Statement}

The authors have no conflicts of interest to disclose.

\section{Funding Sources}

The authors received no specific funding for this work. 


\section{References}

1 Kiernan MC, Vucic S, Cheah BC, Turner MR, Eisen A, Hardiman O, Burrell JR, Zoing MC: Amyotrophic lateral sclerosis. Lancet 2011; 377:942-955.

2 Chio A, Mora G, Lauria G: Pain in amyotrophic lateral sclerosis. Lancet Neurol 2017; 16:144-157.

3 Arthur KC, Calvo A, Price TR, Geiger JT, Chio A, Traynor BJ: Projected increase in amyotrophic lateral sclerosis from 2015 to 2040. Nat Commun 2016;7:12408.

4 Gladman M, Zinman L: The economic impact of amyotrophic lateral sclerosis: a systematic review. Expert Rev Pharmacoecon Outcomes Res 2015;15:439-450.

5 Connolly S, Galvin M, Hardiman O: End-oflife management in patients with amyotrophic lateral sclerosis. Lancet Neurol 2015; 14:435-442.

6 del Aguila MA, Longstreth WT, McGuire V, Koepsell TD, Van Belle G: Prognosis in amyotrophic lateral sclerosis: a population-based study. Neurology 2003;60:813-819.

7 Tsai MJ, Hsu CY, Sheu CC: Amyotrophic lateral sclerosis. N Engl J Med 2017;377:1602.

8 Wells RE, Phillips RS, Schachter SC, McCarthy EP: Complementary and alternative medicine use among US adults with common neurological conditions. J Neurol 2010;257 1822-1831.

9 Yadav V, Bever C Jr, Bowen J, Bowling A, Weinstock-Guttman B, Cameron M, Bourdette D, Gronseth GS, Narayanaswami P: Summary of evidence-based guideline: complementary and alternative medicine in multiple sclerosis: report of the guideline development subcommittee of the American Academy of Neurology. Neurology 2014;82 1083-1092.
10 Fox RJ: Complementary and alternative medicine in multiple sclerosis. Neurology 2014; 82:e103-e107.

11 Alves PD, McClelland J, Morris ME: Complementary physical therapies for movement dis orders in Parkinson's disease: a systematic review. Eur J Phys Rehabil Med 2015;51:693704.

12 Adams J, Andrews G, Barnes J, Broom A, Magin $\mathrm{P}$ (eds): Traditional, complementary and integrative medicine: an international reader. London, Palgrave Macmillan, 2012.

13 Bedlack RS, Joyce N, Carter GT, Paganoni S, Karam C: Complementary and alternative therapies in amyotrophic lateral sclerosis. Neurol Clin 2015;33:909-936.

14 Moher D, Liberati A, Tetzlaff J, Altman DG; PRISMA Group: Preferred reporting items for systematic reviews and meta-analyses: the PRISMA statement. PLoS Med 2009; 6:e1000097.

15 Adams J, Barbery G, Lui CW: Complementary and alternative medicine use for headache and migraine: a critical review of the literature. Headache 2013;53:459-473.

16 Peng W, Adams J, Sibbritt DW, Frawley JE: Critical review of complementary and alternative medicine use in menopause: focus on prevalence, motivation, decision-making, and communication. Menopause 2014;21: 536-548.

17 Adams J, Lui CW, Sibbritt D, Broom A, Wardle J, Homer C, Beck S: Women's use of complementary and alternative medicine during pregnancy: a critical review of the literature. Birth 2009;36:237-245.

18 Wasner M, Klier H, Borasio GD: The use of alternative medicine by patients with amyotrophic lateral sclerosis. J Neurol Sci 2001; 191:151-154.
19 Pan W, Chen X, Bao J, Bai Y, Lu H, Wang Q, Liu Y, Yuan C, Li W, Liu Z, Liu J: The use of integrative therapies in patients with amyotrophic lateral sclerosis in Shanghai, China. Evid Based Complement Alternat Med 2013; 613596.

20 Hanisch F, Skudlarek A, Berndt J, Kornhuber ME: Characteristics of pain in amyotrophic lateral sclerosis. Brain Behav 2015;5:e00296.

21 Vardeny O, Bromberg MB: The use of herbal supplements and alternative therapies by patients with amyotrophic lateral sclerosis (ALS). J Herb Pharmacother 2005;5:23-31.

22 Chen L, Zhang B, Chen R, Tang L, Liu R, Yang Y, Yang Y, Liu X, Ye S, Zhan S, Fan D: Natural history and clinical features of sporadic amyotrophic lateral sclerosis in China. J Neurol Neurosurg Psychiatry 2015;86:1075-1081.

23 Jefferies KA, Bromberg MB: The role of a clinical pharmacist in a multidisciplinary amyotrophic lateral sclerosis clinic. Amyotroph Lateral Scler 2012;13:233-236.

24 Kim S, Chung SE, Lee S, Park J, Choi S, Kim S: Experience of complementary and alternative medicine in patients with amyotrophic lateral sclerosis and their families: a qualitative study. Amyotroph Lateral Scler Frontotemporal Degener 2016;17:191-197.

25 Olsen SA: A review of complementary and alternative medicine (CAM) by people with multiple sclerosis. Occup Ther Int 2009;16: 57-70.

26 Hardiman O: Multidisciplinary care in ALS: expanding the team. Amyotroph Lateral Scler 2012;13:165.

27 Karam CY, Paganoni S, Joyce N, Carter GT, Bedlack R: Palliative care issues in amyotrophic lateral sclerosis: an evidenced-based review. Am J Hosp Palliat Care 2016;33:8492. 